\title{
Análise de "campaignposters": um repensar sobre a educação ambiental ${ }^{1}$
}

\author{
Análisis de "campaignposters": un repensar sobre la \\ educación ambiental
}

\section{Analysis of campaign posters: rethinking about environmental education}

\author{
Aline Cristina Fernandes ${ }^{2}$ \\ Vera Lúcia Lopes Cristovão ${ }^{3}$
}

\begin{abstract}
RESUMO: Este trabalho tem por objetivo analisar as visões de Educação Ambiental presentes nos textos constituintes de uma unidade de um livro didático de Língua Inglesa (FRANCO; TAVARES, 2015) do sexto ano do Ensino Fundamental II, com base no gênero de texto Campaign posters (Cartazes de campanha), relacionado ao tema Save the animals (Salve os Animais). Para tanto, ancoramos nosso estudo nos pressupostos teórico-metodológicos do Interacionismo Sociodiscursivo (BRONCKART, 1997/2009) e no ensino de línguas com base em gêneros (SCHNEUWLY; DOLZ, 2004). Propomos uma discussão sobre os conceitos de Livro Didático (LD) (BONINI, 2003; 2004, 2011) enquanto Suporte (MARCUSCHI, 2003) ou Gênero de texto (VENTURI, 2008). Consideramos também as visões de Meio Ambiente e Educação Ambiental (TOZONIREIS, 2007) presentes em cada texto que compõe a unidade do (LD) investigada. Os resultados apontam para o reconhecimento da importância do conceito de sustentabilidade no processo de desenvolvimento da formação crítica dos estudantes da Educação Básica.
\end{abstract}

PALAVRAS-CHAVE: Livro didático. Gêneros de texto. Educação ambiental.

\footnotetext{
${ }^{1}$ Gostaríamos de agradecer ao CNPQ, pelo apoio ao projeto "Práticas sociais e discursivas sobre meio ambiente em tempos globalizados: implicações e perspectivas para educação em língua estrangeira", processo no. 308754/2015-8, por meio da concessão da bolsa de produtividade em pesquisa à segunda autora.

2Mestranda em Estudos da Linguagem (PPGEL) pela Universidade Estadual de Londrina. Atualmente, Professora Efetiva de Língua Inglesa, da SEED- Secretaria de Estado da Educação - Núcleo Regional de Goioerê. afernandesletras@gmail.com.

${ }^{3}$ Professora associada da Universidade Estadual de Londrina (UEL), membro do Programa de PósGraduação em Estudos da Linguagem (PPGEL-UEL) e líder do grupo de pesquisa Linguagem e Educação (desde 2002). Doutora pela Faculdade de Psicologia e Ciências da Educação da Universidade de Genebra.veraluciacristovao@gmail.com
} 
RESUMEN: Este trabajo tiene por objetivo debatir perspectivas de Educación Ambiental presentes en los textos presentes en una unidad de un libro didáctico de Lengua Inglesa (FRANCO, TAVARES, 2015) del sexto año de la Enseñanza Fundamental II, con base em el género de texto Campaign posters (Carteles de campaña), relacionado al tema Save the animals (Salve los Animales). Para ello, anclamos nuestro estudio en los presupuestos teórico-metodológicos del Interaccionismo Sociodiscursivo (BRONCKART, 1997/2009) y en la enseñanza de lenguas basadas en géneros (SCHNEUWLY, DOLZ, 2004). Proponemos una discusión sobre los conceptos de libro de texto (LD) (BONINI, 2003, 2004, 2011) como ayuda (MARCUSCHI, 2003) o género de texto (VENTURI, 2008). También consideramos las visiones de medio ambiente y educación ambiental (TOZONIREIS, 2007) presentes en cada texto que constituye la unidad de (LD) investigada. Los resultados apuntan al reconocimiento de la importancia del concepto de sostenibilidad em el proceso de desarrollo de la educación crítica de los estudiantes de educación básica.

PALABRAS-CLAVE: Libro de texto. Géneros de texto. Educación ambiental.

ABSTRACT: This work aims to discuss perspectives of environmental education in the texts which constitute an unit of an English language textbook (FRANCO; TAVARES, 2015) to the sixth grade of elementary school II, based on the textual genre campaign posters, related to the theme Save the Animals. For this, we anchored our study in the theoretical-methodological assumptions of socio-discursive interactionism (BRONCKART, 1997/2009) and in the language teaching based on textual genres (SCHNEUWLY; DOLZ, 2004). We propose a discussion about the concepts of textbook (LD) (BONINI, 2003, 2004, 2011) as support (MARCUSCHI, 2003) or a textual genre (VENTURI, 2008). We also consider the visions of environment and environmental education (TOZONI-REIS, 2007) present in each text that are part of the analyzed (LD) 's unit. The results point to the recognition of the sustainability concept importance in the process of developing critical education of basic education students.

KEY WORDS: Textbook. Textual genres. Environmental education.

\section{Introdução}

Rápidas mudanças em favor do desenvolvimento da produção e do consumo na sociedade moderna fizeram emergir novos problemas como aqueles relacionados às questões ambientais (TEIXEIRA, 2013). Essa situação deflagrou a necessidade da Educação Ambiental (EA) como uma forma de lidar com os problemas socioambientais.

Uma maneira de amenizar os danos ambientais é ensinar a população por meio da EA. Um marco histórico muito importante para a (EA) foi a Conferência Intergovernamental de Educação Ambiental em Tbilisi em 1977, na qual Dias e 
Bonfim (2011, p. 4), a definem como um processo "[...] dinâmico, integrativo, transformador, participativo, abrangente, globalizador, permanente e contextualizador." A Conferência Intergovernamental de Tbilisi (1977) traçou objetivos, finalidades, princípios e 41 recomendações para a (EA), subsidiando a educação e a formação social para as realidades locais, regionais e mundiais. Entretanto, Leff (2009, p. 494) nos alerta para a simplificação dos princípios estabelecidos nesta Conferência, diminuindo-os à prática de uma (EA) conservadora disseminadora de informações para "conscientizar" os sujeitos.

A partir dessas bases, desenvolvidas na conferência de Tbilisi, relacionadas ao meio ambiente, no Brasil estabeleceu-se a lei número 9.795/99, determinando a implantação da (EA) para os níveis infantil, fundamental e médio da educação básica, e também para os níveis de educação superior, especial, profissional e educação de jovens e adultos.

No presente trabalho propomos a análise dos textos de uma unidade que compõe um Livro didático (LD), objetivando relacionar as visões de meio ambiente e conceito de sustentabilidade no ensino de línguas que perpassam os textos. E, a partir disso, quais seriam as contribuições desse ensino de EA, nas aulas de Língua Inglesa na educação básica.

O texto organiza-se em uma explicação do referencial teórico que norteia o trabalho. Fazendo uma relação dos conceitos de gêneros de textos, livro didático: suporte ou gênero, a didatização de textos.

\section{Gêneros de textos}

O início do século XXI trouxe uma profusão de estudos de gêneros e ensino no Brasil. Sendo assim, com a valorização desta perspectiva, os materiais didáticos adotaram os gêneros como um meio para de ensino de línguas em nosso país.

Para Marcuschi (2010), o discurso materializa-se em possibilidades de ação social de acordo com a situação comunicativa; é evidente que aspectos socioculturais permeiam os gêneros textuais. Uma das características dos 
gêneros é a plasticidade, isto é, a capacidade de adaptarem-se ao contexto em que se inserem.

Entendendo a plasticidade do gênero e considerando o contexto em que textos circulam, a determinação de um gênero textual pode ter influência de aspectos formais, sócio-comunicativos ou funcionais; além disso, o suporte ou até mesmo o ambiente influenciam na composição e, consequentemente, na definição do gênero. Marcuschi analisa que,

\begin{abstract}
Usamos a expressão gênero textual como uma noção propositalmente vaga para referir os textos materializados que encontramos em nossa vida diária e que apresentam características sócio-comunicativas definidas por conteúdos, propriedades funcionais, estilo e composição característica. (MARCUSCHI, 2010, p. 4).
\end{abstract}

Pode-se afirmar que com o desenvolvimento da cultura de uma sociedade, o gênero de texto adapta-se correspondendo às mudanças sociais, e isto reflete os modos de interação social.

Ao dominar um gênero textual o sujeito atende linguisticamente aos objetivos intrínsecos a determinadas situações sociais. No entanto, isso não significa que se os interlocutores souberem apenas as formas linguísticas inerentes ao gênero, conseguirão atingir o objetivo da comunicação eficaz. Segundo Bronckart (1999 apud MARCUSCHI, 2010, p. 10), "a apropriação dos gêneros é um mecanismo fundamental de socialização, de inserção prática nas atividades comunicativas humanas". Ao inserir-se em uma esfera e situação de comunicação, a função do gênero tem prioridade em relação ao objetivo comunicativo que se pretende alcançar. Assim sendo, mesmo que falte algum elemento linguístico, se a função comunicativa for atingida, o gênero foi utilizado com sucesso.

Segundo Miller (1984 apud MARCUSCHI, 2010, p. 13), deve-se priorizar a ação social realizada pelo gênero, porém, não podemos desconsiderar a importância dos elementos composicionais linguístico-discursivos. Para Bakhtin (1997 apud MARCUSCHI, 2010, p. 13), a construção composicional, conteúdo temático e estilo caracterizam-se como constituintes do gênero. Entretanto, os 
elementos culturais influenciam os gêneros, e os mesmos revelam em suas entrelinhas características da organização social a que pertencem.

Na maioria dos Livros didáticos (LD) de Língua Inglesa, são utilizados os gêneros de texto para possibilitar a que os estudantes, a partir de experiências com a linguagem, e com os conhecimentos linguísticos apreendidos, apropriemse dos mesmos e transformem as práticas do cotidiano.

\section{Livro didático: suporte ou gênero?}

Marcuschi (2003) defende a importância de analisar a influência do suporte para a apresentação dos gêneros. A relação suporte e gênero textual não é linear, pois há situações em que o gênero depende do suporte; o suporte influencia o gênero e o gênero influencia o suporte. Marcuschi (2003) afirma que é importante saber o dinamismo do suporte, isto é, o grau de influência do mesmo ao gênero.

Suporte, segundo Marcuschi (2003), é um local palpável ou cibernético, com forma específica e com a utilidade de afixar e expor o texto, para fazê-lo coerente para objetivos comunicativos. Além disso, o autor discute sobre a seletividade e neutralidade do suporte em relação ao gênero.

Ao afirmar que o (LD) é um suporte para os gêneros, Marcuschi propõe uma reflexão sobre a funcionalidade do texto que está no (LD), se permanece com o objetivo original ou didático. $\mathrm{O}$ autor explica que

o livro didático tem interesses e objetivos específicos na escolha de certos gêneros (busca gêneros adequados a certos objetivos do ensino, visa a uma variação ampla, contempla os mais frequentes, exemplifica peculiaridades estruturais e funcionais), o que não atinge a estrutura dos gêneros, mas sua funcionalidade imediata no que tange ao interesse e não à função. Mesmo uma propaganda continua propaganda no livro didático, mas ali ela não serve mais aos propósitos originais e agora opera como exemplo para produzir tais objetivos. Será que se poderia dizer que isto a torna um gênero diferente? Creio que se poderia postular aqui a sugestão de uma reversibilidade de função para o caso dos textos do livro didático. [...] Por isso, o livro didático é um suporte e os gêneros que ali figuram mantém suas funções, embora não de forma direta, já que assumem o propósito de operarem naquele 
contexto como exemplos para produção e compreensão textual. (MARCUSCHI, 2003, p. 12).

O autor considera a materialidade do (LD) enquanto um suporte. O qual é composto por páginas, capa, contracapa, encadernação etc. Marcuschi (2003) afirma que os gêneros inseridos no (LD), didatizados e com objetivos pedagógicos não perdem a identidade original, porém a função desses gêneros não é a mesma assumida na esfera de circulação original. Assim, o autor sugere uma "reversibilidade de função" (MARCUSCHI, 2003, p. 12), pois a função do gênero é modificada pelos objetivos de ensino de línguas.

Para Bonini (2003) o conceito de gênero e veículo é bem mais complexo do que imaginamos. $O$ autor discute as contradições em relação ao veículo de comunicação e gênero de texto em seu texto "Veículo de Comunicação E Gênero Textual: Noções Conflitantes".

Bonini (2003) ancora-se em Swales (1990) e Bhatia (1993) para explicar que os gêneros têm uma base forte no propósito comunicativo socialmente exercido. $E$ isto influenciará os elementos composicionais e ações de linguagem por meio dos mesmos. O gênero é entendido, portanto, como um componente do código e não um suporte físico de circulação da linguagem.

O autor supracitado considera que vários elementos sociais (suporte físico, estrutura textual e de encaixe da enunciação, papel e propósitos social do enunciador) são indicadores para o objetivo da função da ação da linguagem. Sendo assim, caracteriza o gênero como algo que vai além de estrutura do texto, pois ele é composto um processo de elementos que visa à significação. (BONINI, 2011).

Então, a identidade do gênero provém da interação entre textos e sujeitos. Assim, os gêneros e suportes não se distinguem. Pois, os gêneros além de ter funções de comunicar e ação de linguagem, podem ter funções de apoio e organização à outra ação social. $\mathrm{O}$ autor cita exemplos do plano de aula, lista de compras e passagem.

O autor relaciona as noções de veículo e gênero a partir do exemplo o jornal. Este é composto por vários gêneros que passaram por modificações até 
chegarem à fase da impressão do material. Considera então, o jornal como veículo de várias seções, pois o leitor não lerá necessariamente todo o jornal e sim as informações que o interessarem. Mas, por outro lado, pelo fato de o jornal ser composto pela mesma funcionalidade os gêneros que o constitui, seria ele também um gênero. E por ser composto por vários gêneros, pode ser considerado um hipergênero.

A partir de explicações e exemplos do autor sobre gênero de texto e veículo, pode-se entender que o mesmo considera (LD) como hipergênero, pois é composto por vários gêneros e tem a mesma funcionalidade dos textos que 0 constituem: ser base para o ensino de línguas.

Venturi (2008, p. 62) utiliza o termo manual didático (MD) ao invés de (LD). A autora compara o MD com as esferas de comunicação, as quais permitem trocas de enunciados. Segundo ela, o MD funciona como um meio de reunir esferas de troca, por isto o (MD) seria uma "megaesfera de troca". Por conter vários gêneros de texto, a autora define o MD como um gênero didático, por ser repleto de estratégias de ensino.

Para Venturi (2008, p. 63) o "gênero didático do manual de L2 agrupa várias esferas de circulação, transpondo didaticamente os textos com a principal finalidade de fazer com que os alunos aprendam a língua e adquiram aspectos culturais importantes.". É evidente a funcionalidade do texto didatizado, pois a autora afirma que são utilizados gêneros recorrentes do cotidiano, nos quais se destacam partes gramaticais principais, e o objetivo de ensino é a aprendizagem de fatores linguísticos e discursivos.

A autora ressalta que existem trocas de suportes ao retirar os textos das esferas de comunicação real e inseri-los no (MD), com objetivo de ensino. Por outro lado, considera o (MD) como um gênero, pois este possui objetivo de interação e elementos composicionais próprios do contexto em que circula.

É visto que ao encarar os interlocutores, autores, contexto de circulação, objetivos mercadológicos e funcionalidade de um livro, é o gênero de texto presente no (LD) que interagirá com os leitores. Além disso, oportunizará diferentes reações; proporcionará a fruição da criatividade por meio da leitura e 
experiências diversas a partir dos conhecimentos prévios do leitor. Por meio dos textos do (LD), o estudante assume diversos papeis sociais, identificar-se com um personagem a partir da linguagem pelo qual usa para expressar-se em diferentes contextos e aprende os mais variados conceitos científicos.

Para Souza e Viana (2011), o (LD) é permeado por fatores exteriores como: teorias de ensino, documentos oficiais e metodologia docente. As influências externas tornam o (LD) um objeto de mercado e uma base para 0 ensino por influenciar sua organização. É também um objeto cultural plurilinguístico propenso à transformação, pois possui uma natureza discursiva.

Uma característica do (LD) é a função metalinguística dos textos na utilização de textos didatizados para trabalhar elementos específicos. A estrutura composicional do (LD) contém vários gêneros que servem de base para as atividades. O (LD) é considerado um objeto cultural propenso à transformação, pois possui uma natureza discursiva. Souza e Viana $(2011$, p. 8) em análise a (LD) de Português afirmam que

\footnotetext{
De modo geral, as análises confirmam a presença de uma construção discursiva para o (LD)P, assentando a sua compreensão como um gênero do discurso complexo, híbrido, plurilinguístico entretecido pela configuração de outros gêneros autônomos e independentes em sua composição, demonstrando, portanto, que o (LD)P não se configura como um suporte textual, mas trata-se de um objeto histórico cuja totalidade material discursiva é composta por outros gêneros que aponta para uma unidade de gênero discursivo complexo que sugere análises discursivas.
}

Assim sendo, as autoras supracitadas ressaltam o caráter de gênero do discurso do (LD), pois além de ser mediador do conhecimento, ele possui historicidade, objetivo, estrutura composicional, estilo, tema, acabamento discursivo, autor e interlocutores. (SOUZA; VIANA, 2011).

Entendemos, portanto, o (LD) enquanto um gênero, pois ele caracterizase por sua transcendência de textos e caráter de gênero complexo, que contém textos de caráter primários e secundários, circula na esfera social escolar, tem público específico, e funcionalidade própria voltada ao ensino por meio de vários gêneros de texto. 
Sendo assim, Souza e Viana (2011, p. 9), confirmam que

\begin{abstract}
Teoria Dialógica da Linguagem, representada aqui, sobretudo no conceito de gêneros discursivos, revelou-se como uma rica possibilidade para se compreender o (LD)P em seu caráter discursivo. Pensá-lo com uma unidade comunicacional imprensa na cadeia discursiva de determinada esfera da atividade humana, implica considerá-lo como um enunciado que possui um elo com outros enunciados e, por isso, dinâmico, sócio-histórico cultural tematizado em estrutura composicional, estilo e tema específicos, acabamento discursivo, intercalação de gêneros, continuum histórico. Enfim, uma unidade discursiva complexa que se enuncia por meio de outros enunciados, possui um autor e se destina a interlocutores específicos, portanto, um enunciado em gênero do discurso.
\end{abstract}

Ao possuir a funcionalidade de ensino de língua, muitos textos são adaptados para atingirem o objetivo de ensino e também de comercialização. Ao serem retirados do contexto original são "facilitados" para auxiliar no processo de aprendizagem, por isto há a problematização em torno dos conceitos de didatização e autenticidade dos textos presentes nos (LD).

\title{
A didatização de textos
}

Marcuschi (2003) explica a mudança de função dos gêneros quando saem de sua esfera de circulação original. O autor exemplifica a partir das cartas pessoais. Se elas são divulgadas, fazendo parte de livros, elas não perdem sua identidade de gênero, porém a funcionalidade é outra.

Venturi (2008, p. 63) explica que ao mudar o contexto, e, consequentemente, de suporte, os gêneros se modificam e passam a ser outro gênero. Ao explicar essa mudança, a autora exemplifica "placa de aviso" como um gênero que, se estiver em diferentes suportes e contextos, implica em reações, entendimentos diferentes no leitor. Por exemplo, "se a mensagem Cuidado! Não se aproxime. Perigo de choque, estiver escrita numa placa de alumínio perto de uma cerca, o impacto, o entendimento e a reação do leitor serão bem diferentes do que ler a placa fotografada e transporta num jornal ou livro didático." (VENTURI, 2008, p. 63). 
Assim, ao retirar o texto da esfera de circulação e adaptá-lo, modificamse os objetivos, os destinatários, e a funcionalidade. A presença de textos não autênticos em (LD) é bastante questionada por alguns autores, devido ao modo que o gênero é trabalhado, o que evidencia uma perspectiva teóricometodológica de ensino de línguas

quando diz que, geralmente, os manuais de ensino de língua estrangeira negligenciam os aspectos linguísticos. Os textos são demasiadamente simplificados não se considerando a presença dos textos autênticos [...] tornando artificial a maneira de lidar-se com a linguagem. (MORDENTE 1994 apud VENTURI, p. 67).

Sendo assim, ao realizar a transposição didática ${ }^{4}$, Venturi (2008, p. 68) afirma que os textos didáticos são reunidos de acordo com o objeto de ensino, como por exemplo, o ensino de estruturas linguísticas.

Bonini (2004) ressalta a didatização de textos, ao afirmar que os mesmos têm seus objetivos originais modificados, a partir da mudança de esfera de circulação. É possível observar isto a seguir,

É prudente considerar, contudo, (como salientam Schneuwli e Dolz, 1999) que, ao entrar na escola, o gênero necessariamente sofre um desdobramento. Ele deixa de pertencer ao seu ambiente social típico de origem para se transformar em objeto de ensino. A consideração desse aspecto deve conduzir os profissionais do ensino inevitavelmente à reflexão, pois a transposição dos saberes sobre os gêneros não é direta. Pode-se dizer, inclusive, que há uma infinidade de possibilidades de trabalho didático dentro de uma escala que vai da prática menos ao mais autônoma - em relação ao projeto de dizer do aluno e em relação ao meio social de origem do gênero (BONINI, 2004, p. 2).

Ressalta-se assim, a importância do professor ser consciente dessa didatização, e ter uma metodologia, para fazer um trabalho eficaz por meio dos gêneros de texto.

\footnotetext{
${ }^{4}$ As expressões "a transposição didática" ou "a transposição" designam o conjunto da teoria da transposição didática, no livro de Chevallard: La transposition didactique, du savoir savant au savoir enseigné, La Penséesauvage, Lyon (1985/1991). Esse livro introduz a teoria da transposição didática no mundo didático. Recomendo a citação do autor e uma passagem pelos textos que a ele se referem.
} 
Wallace (1996) nos faz refletir sobre o ensino de uma língua estrangeira e a didatização de textos, com o foco em uma metodologia de ensino que auxilie a aprendizagem e associe a fala e a escrita. Ao defender o ensino pela leitura, 0 autor afirma que ao selecionar textos para o ensino, o docente não deve focar no léxico recorrente no mesmo, mas sim, em textos de conteúdos ricos, motivadores que possibilitem o trabalho com estratégias de leitura.

O autor confirma a complexidade dos textos autênticos e traz questionamentos sobre a simplificação dos mesmos, para facilitar a aprendizagem. É possível perceber que a didatização de textos que foca no trabalho com o léxico é criticada, pois segundo Wallace (1996) a apropriação do significado de uma palavra acontece com a recorrência que o estudante tem contato com ela em contextos variados.

Ao referenciar um trabalho de Meinhof (1987), Wallace (1996) pontua a problemática evidenciada pelo autor, a partir do momento em que o texto tem um objetivo pedagógico ele perde a autenticidade, pois não está em seu contexto sociocultural.

Breen (1985 apud WALLACE, 1996) expõe tipos de autenticidade para o contexto de sala de aula. A autenticidade de textos pode auxiliar em situações de ensino, e por isso o professor deve saber explorar a sua autenticidade para propiciar maior interação do aluno com o texto e a aprendizagem,

1. Autenticidade do texto que nós podemos usar como um recurso ${ }^{5}$ material para nossos aprendizes

2. Autenticidade para a interpretação própria do aprendiz dos textos

3. Autenticidade para as atividades úteis para a aprendizagem da linguagem

4. Autenticidade da situaçã̃o social atual da linguagem de sala de aula.

\footnotetext{
5 Tradução da autora.
} 
Percebe-se que a (não) autenticidade de um texto não pode ser vista como um impedimento para o ensino. Pois o mais importante é propósito comunicativo de cada atividade. Portanto, o (LD) é repleto de gêneros autênticos e didatizados, e é visto como um mediador de práticas educativas no contexto do ensino básico. O que importa é modo que o conteúdo é trabalhado e discutido, pois influencia na formação dos estudantes.

\section{Educação ambiental: percepções sobre o meio ambiente}

Trein (2012), ao discutir o tema Educação Ambiental (EA), sugere investimento na formação docente, pois no contexto escolar é realizado um trabalho precário. E com isto está acontecendo a "fragilização do compromisso ético-político que dá sentido à identidade profissional dos professores que exercem uma educação crítica." (TREIN, 2012, p. 304). A partir da realidade do trabalho com a EA, o autor traz uma revisão sobre fatos históricos sobre a crise ambiental no mundo.

A natureza transformou-se devido ao trabalho, que inicialmente objetivava apenas a subsistência do homem, mas em seguida, visou à lucratividade. À medida que a sociedade mudava a natureza também sofria mudanças. Os avanços na sociedade facilitaram a compra e a venda, para obter mais lucro e benefícios por meio das riquezas naturais. $\mathrm{E}$, com o passar do tempo, foi sendo parte da cultura social explorar a natureza. Marx criticou esta atitude social causada inicialmente pelo trabalho, em sua obra Manuscritos Econômicos e Filosóficos de 1844,

A natureza é o corpo inorgânico do homem. O homem vive da natureza, ou também, a natureza é o seu corpo, com o qual tem de manter-se em permanente intercâmbio para não morrer. Afirmar que a vida física e espiritual do homem e a natureza são interdependentes significa apenas que a natureza se inter-relaciona consigo mesma, já que 0 homem é uma parte da natureza (MARX 2010 apud TREIN, 2012, p. 305-306) 
Nos primórdios da humanidade, o trabalho surgiu como um fator de subsistência perante a necessidade, porém com o desenvolvimento social, o mesmo tem a função de dar conforto às pessoas, o que está estritamente relacionado com o consumismo da sociedade.

O homem preocupa-se com os recursos naturais quando estes estão escassos e não podem mais contribuir para produção e venda em larga escala. E assim o comércio encarece mercadorias, e a população é prejudicada de várias maneiras. Devemos pensar até que ponto a preocupação é motivada pelo sentimento de se sentir parte integrante ou sentir-se possuidor.

Com o aparecimento dos problemas ambientais a partir de meados do século $\mathrm{XX}$, a sociedade começou a desenvolver programas para preservar o meio ambiente. De acordo com Trein, (2012, p. 307) "temos agora a "revolução verde industrial" ou simplesmente a "economia verde", um dos eixos centrais da Conferência RIO+20." A preocupação em preservar é sempre importante, porém parece que "ser verde" tornou-se moda entre as empresas, por exemplo, de tempos em tempos, quando uma empresa quer melhorar o marketing perante a sociedade, a mesma lança uma campanha relacionada ao meio ambiente.

Loureiro (2012 apud TREIN, 2012, p. 308) discute a contradição do termo "desenvolvimento sustentável". O desenvolvimento acelera o consumismo, exploração desmedida de recursos naturais, há algumas tecnologias de energia "sustentáveis" ou alimentos orgânicos, porém, são caras e não são acessíveis para toda a sociedade, evidenciando assim a desigualdade e desrespeito à natureza.

Mézáros (2007) define sustentabilidade como

[...] estar realmente no controle dos processos sociais, econômicos e culturais vitais, pelos quais os seres humanos não apenas sobrevivem, mas também encontram realização, de acordo com os desígnios que estabeleceram para si mesmos, ao invés de ficarem à mercê de forças naturais imprevisíveis e determinações socioeconômicas quase naturais (apud TREIN, 2012, p. 308). 
Deste modo, as ações sustentáveis desenvolvem-se por meio do conhecimento sobre a relação social estabelecida com natureza historicamente. Assim sendo, temos poder de escolha e decisão em relação às imposições sociais e (ou) comerciais encaradas como "normal" pela sociedade capitalista. Então, é possível problematizar quais tipos de práticas escolares acontecem, se são reprodutivistas de conceitos rasos e de senso comum, ou práticas sustentáveis que ensinam o respeito e compromisso social com o ambiente em que estamos inseridos.

O termo educação "ambiental" é questionado por Carvalho (2004 apud TREIN, 2010, p. 310). Segundo o autor, humanos e natureza interagem a todo $o$ momento, e, se um dos objetivos da educação é preparar o sujeito para o mundo do trabalho, é papel da escola propagar esta relação de respeito, a qual influencia o modo que as crianças e jovens entendem e relacionam-se com a natureza. Em nosso país, a EA é um tema consideravelmente novo, e gradativamente está sendo inserido no currículo escolar de modo interdisciplinar.

É um desafio para o profissional da educação, articular conhecimentos ambientais para colaborar com a mudança das relações sociais. Contudo, este é um trabalho que deve ser debatido e experimentado para analisarmos práticas significativas que possam ser perpetuadas.

Reigada e Tozoni-Reis (2004) em um trabalho prático com crianças, perceberam que o conceito de meio ambiente para estas eram apenas árvores e animais. As autoras denominaram esta atitude como representações "naturalistas", pois os sujeitos não se sentiam parte da natureza.

A partir disto, sentiram a necessidade de trabalhar a comunidade que essas crianças viviam, para que elas entendessem que meio ambiente inclui o espaço natural e o construído pelas relações sociais como convivência com a natureza. Ao trabalharam juntas, as crianças desenvolveram competências de cooperação e por meio de dinâmicas e desafios deram dicas sobre como melhorar a comunidade. E por meio de parcerias com órgãos públicos realizaram algumas sugestões dentro das possibilidades locais.

Segundo Tozoni-Reis (2006), 
A educação ambiental crítica e emancipatória exige que os conhecimentos sejam apropriados, construídos, de forma dinâmica, coletiva, cooperativa, contínua, interdisciplinar, democrática e participativa, voltados para a construção de sociedades sustentáveis. (TOZONI-REIS, 2006, p. 93).

É evidente que realizar uma (EA) não é tarefa simples. Exige muito compromisso entre professores, equipe de trabalho e dos estudantes participantes, pois a interação é essencial para um trabalho significativo.

A preocupação com o meio ambiente pode parecer uma contradição, pois o meio ambiente e os seres vivos são afetados pelo próprio homem por meio da tecnologia e do desenvolvimento. A autora utiliza o exemplo "marco histórico a bomba atômica sobre Hyroshima e Nagazaki no final da Segunda Guerra Mundial, em 1945 - expressão do poder político e econômico de um país sobre o mundo social e natural.". Pois o homem utiliza os recursos naturais para satisfazer a necessidade, mostrando seu poder de destruição da vida natural (TOZONI-REIS, 2006, p. 94).

A maior tarefa da EA é a busca pela sustentabilidade, este conceito é muito mais complexo do que imaginamos. De acordo com as documentações que regem a (EA)

[...] para uma sustentabilidade eqüitativa é um processo de aprendizagem permanente, baseado no respeito a todas as formas de vida. Tal educação afirma valores e ações que contribuem para a transformação humana e social e para a preservação ecológica. Ela estimula a formação de sociedades socialmente justas e ecologicamente equilibradas, que conservem entre si a relação de interdependência e diversidade. Isto requer responsabilidades individual e coletiva no nível local, nacional e planetário. Fórum Internacional das ONGs (1995 apud TOZONI-REIS, 2006, p. 95-96).

O conceito de sustentabilidade é a base para a EA crítica, pois engloba uma educação "política, democrática, libertadora e transformadora." (TOZONIREIS, 2006, p.96) que orienta-se pela responsabilidade social e respeito pela vida de modo geral. Para realizar este trabalho deve-se organizar atividades com temas geradores (LAYRARGUES, 2001 apud TOZONI-REIS, 2006, p. 97-98) que 
engajem valores e atitudes histórico e políticas, que não sejam apenas informações vagas e descontextualizadas, pois o objetivo é mediar a aprendizagem humana para transformar atitudes locais.

Outro princípio da EA é o conceito de conscientização. Este não objetiva impor um conceito moralizante em relação meio ambiente, ou sobre ações que devem ou não ser feitas no dia a dia, este conceito "não é um resultado imediato da aquisição de conhecimentos sobre os processos naturais, mas a reflexão filosófica e política, carregada de escolhas históricas que resultam na busca de uma sociedade sustentável." (TOZONI-REIS, 2006, p. 106).

Desse modo, quando se desenvolve um trabalho sustentável não significa doutrinar mudança de comportamentos, os educadores devem superar as "propostas educativas ambientais ingênuas e descomprometidas, social e politicamente, em busca de atividades mais consistentes e conseqüentes comprometidas com a construção de sociedades mais justas e igualitárias.". (TOZONI-REIS, 2006, p. 108).

É visto que os docentes têm desafios para trabalhar a EA de um modo contínuo, porém devemos ter iniciativas nos ambientes escolares que incentivem a o desenvolvimento de projetos sociais e a expansão deste conceito de EA crítica e sustentável.

Tozoni-Reis (2001) propõe três visões de meio ambiente nas práticas educação, são elas: natural, racional e histórica. A visão natural objetiva que o homem renda-se e retorne a sentir-se parte da natureza. Assim sendo, "A educação, de prática social construída e construtora da humanidade e das relações homem-natureza e homem-homem, fica reduzida ao papel de adaptadora dos sujeitos ao mundo pré-determinado pelos processos naturais." (TOZONI-REIS, 2001, p. 38) O homem para respeitar a natureza tem que voltar a ter hábitos que evidenciem a dominação natural. Esta visão não visa à integração e interação de homem e natureza, mostrando-se, controladora e autoritária.

A visão racional visa a "preparação - no sentido de adaptação - intelectual dos indivíduos para viverem em sociedade de forma a garantir que os recursos 
naturais não se esgotem." (TOZONI-REIS, 2001, p. 39). Por meio do repasse de conhecimentos ditos como verdades, de geração em geração. $O$ sujeito deve utilizar a racionalidade para aprender sobre a natureza, tirar proveito da mesma para as necessidades e lucratividade, e fazer com que os recursos naturais não acabem. As atitudes expressadas nas atividades são de dominação do homem sobre o meio ambiente.

A visão histórica de meio ambiente valoriza o processo histórico que perpassa as ações culturais coletivas do relacionamento respeitoso e possibilidades de convívio entre homem e natureza. E ressalta a noção de solidariedade.

A EA objetiva desenvolver o relacionamento de humanos e natureza, para que as ações humanas ancorem-se na ética baseada na "apropriação crítica de conhecimentos, atitudes e valores políticos, sociais e históricos.". (TOZONI-REIS, 2001, p. 42) Evidenciando a responsabilidade pela natureza e ambiente que os cercam.

Tozoni-Reis (2001) defende uma formação docente com base na metodologia da interdisciplinaridade que supere a "transferência de verdades" passadas pelas gerações. Repensando até mesmo o modo que o ensino é organizado, para que por meio de uma abordagem histórica surjam possibilidades de aprendizagem sobre as relações sociais sustentáveis entre os sujeitos e a natureza.

A (EA) é lei e deve estar presente em todos os níveis de ensino. Considerando sua obrigatoriedade, o Programa Nacional do Livro e Material Didático (PNLD) aborda em uma ou mais unidades dos materiais que distribui para as escolas públicas, conteúdos relacionados ao meio ambiente. Justificandose assim, a análise de uma unidade que compõe um (LD) do ensino fundamental II.

\section{Método da Pesquisa}


A natureza desta pesquisa é aplicada e tem uma abordagem qualitativa, pois tem o intuito de analisar as visões de Educação Ambiental presentes nos textos constituintes de uma unidade de um livro didático de Língua Inglesa do sexto ano do Ensino Fundamental II (FRANCO; TAVARES, 2015), com base no gênero de texto Campaign posters (Cartazes de campanha), relacionado ao tema Save the animals (Salve os Animais).

A seleção do (LD) para análise foi devido ao mesmo ser utilizado dos anos de 2017 a 2019 nas escolas públicas do Ensino Fundamental II. Em uma cidade do no interior do Paraná, na qual a pesquisadora leciona, no contexto da rede Estadual pública de ensino.

Como categorias de análise da unidade foram realizadas: a)leitura de todos os textos e atividades da unidade; b) contagem do número de textos; c) contagem da recorrência de textos verbais, não verbais e multimodais d) identificação dos gêneros de textos utilizados; e) análise do texto como Pretexto para o ensino de línguas ou Objeto de ensino; f) análise do objetivo original do texto em seu contexto de circulação e o objetivo do mesmo texto, estando didatizado, inserido no (LD), com a funcionalidade voltada ao ensino; g) análise da concepção de meio ambiente presente nos textos.

A partir da análise das atividades, observaram-se diversas visões de EA inseridas nas atividades, que compõem a unidade do (LD). É visto que elas influenciam na formação cidadã dos estudantes em relação à EA.

\section{Análise dos textos da unidade do livro didático}

Os conceitos abordados anteriormente são relevantes para o entendimento da análise dos textos que compõem a unidade. Por isto, defendemos a importância da formação continuada de professores de línguas, pois existem várias perspectivas sobre gêneros de texto, o (LD) suporte ou gênero, a didatização de textos, as percepções sobre o meio ambiente e EA. Ao entender a diferença dos vieses teóricos e metodológicos, os docentes poderão 
se posicionar sobre o ensino e defendem, e, consequentemente, tentar melhorar a metodologia de ensino.

Na seção a seguir, contextualizaremos os elementos composicionais da unidade e os motivos pelos quais esta unidade foi escolhida para análise. Em seguida, observaremos os textos predominantes e suas influências para o objetivo de ensino da unidade. Depois disso, analisaremos as visões de meio ambiente contidas nos textos considerando suas funcionalidades. Também, discutiremos a didatização dos gêneros de texto inseridos na unidade.

\section{A unidade "save the animals"}

A temática abordada nesta unidade enfatiza os animais como seres vulneráveis às ações humanas. Vários textos mostram-nos as dificuldades que esses enfrentam devido às atitudes desrespeitosas pelos seres vivos. A relação de interdependência da convivência dos seres vivos no planeta é visível durante a unidade. Observa-se que a mesma engloba um tema ambiental que ultrapassa o conceito de meio ambiente apenas composto por plantas ou animais.

De acordo com o (LD), os objetivos desta unidade são "falar sobre os animais e protestos; aprender como usar o Imperativo; explorar pôsteres de campanha e estabelecer conexões com Ciências, Artes e Português". O conceito de intertextualidade fica evidente devido aos conceitos que perpassam a temática sobre a vida animal.

As seções deste (LD) são distribuídas em:

Warming Up; Before Reading; Reading; Reading for General Comprehension; Reading for Detailed Comprehension; reading for Critical Thinking; Vocabulary Study; Taking it Further; Language in Use; Listening and Speaking; Writing; Looking Ahead; Extra Reading Extra Videos. (FRANCO; TAVARES, 2015, p. 121).

Um dos objetivos da unidade é explorar pôsteres de campanha. Durante a unidade são trabalhadas quatro campanhas da Peta (People for the Ethical Treatment of Animals) e uma campanha de prevenção ao abuso dos animais. 
É evidente em toda a unidade a recorrência de atividades que contemplam enunciados com verbos no modo imperativo. Por exemplo, nas páginas de abertura da unidade temos os enunciados: "Salve os animais!" e "Ajude-nos!". A função injuntiva de conotação apelativa ressalta a abordagem da temática a ser trabalhada. Os textos que compõem a unidade enfatizam a necessidade do respeito pelos animais em diferentes aspectos tais como: no habitat natural; em zoológicos; na adoção responsável; cuidados com os animais domésticos próprios ou de outras pessoas; a exploração animal na sociedade por indústrias e compaixão pelos animais.

O uso de cada texto, além de ter um objetivo de ensino de língua, tem uma intencionalidade marcada por visões de meio ambiente abordadas pelo (LD). Ressaltando, implicitamente, por meio dos textos e atividades os princípios de EA que estão sendo ensinados aos cidadãos.

\section{Textos predominantes}

A unidade é composta por 21 textos, dentre eles apenas dois não abordam a temática ambiental, pois se relacionam a uma atividade de comparação para a identificação do gênero textual pôster de campanha. No quadro 1 vemos a recorrência dos estatutos dos textos utilizados. 


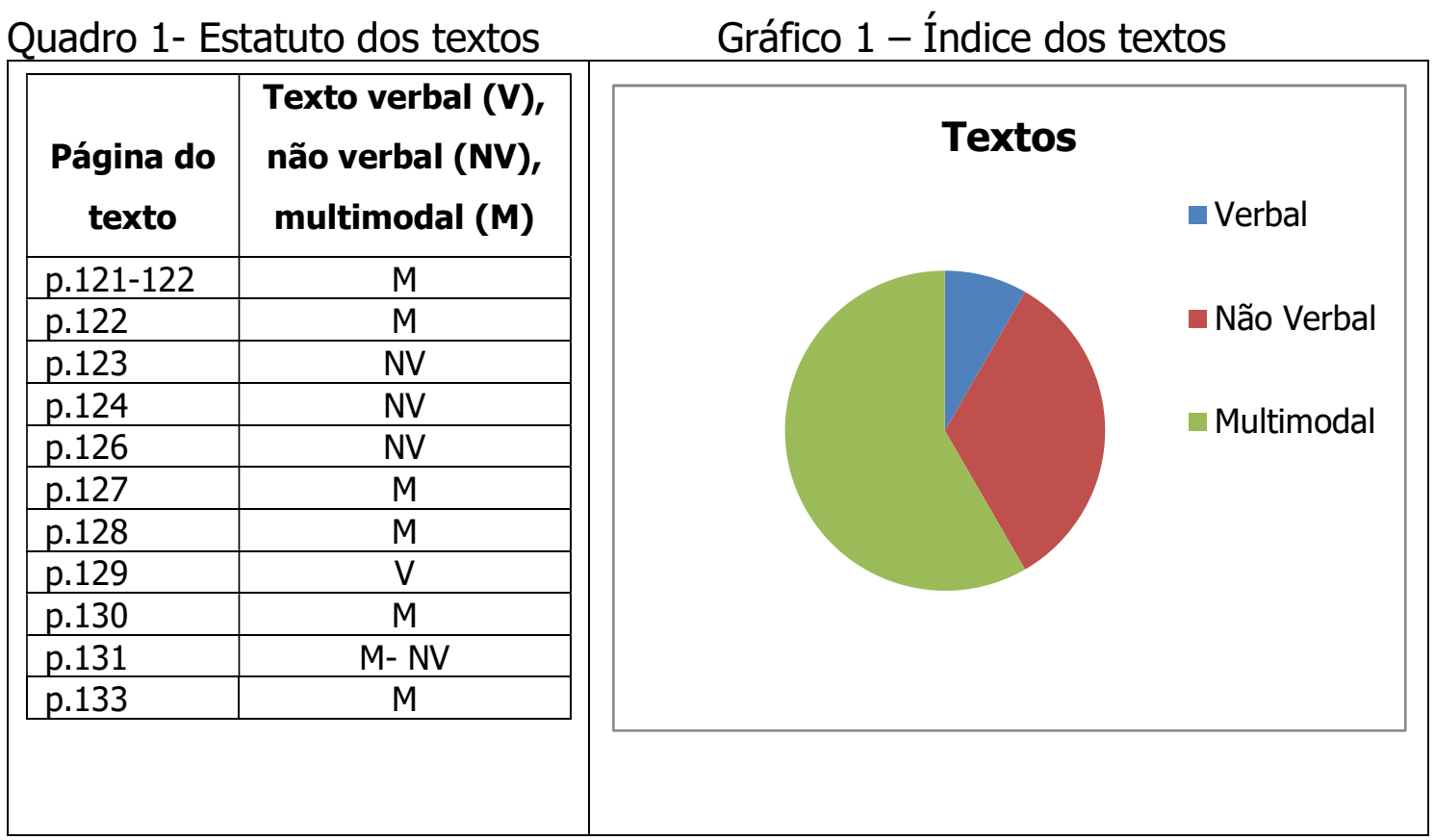

Fonte: as autoras

Em cada página da unidade é visível a recorrência de textos da mesma categoria, isto acontece devido ao objetivo das atividades propostas em cada seção do (LD).

Devido à faixa etária dos estudantes, os textos possuem muitas imagens para representar a situação abordada, tema e conceitos dos textos, com mais facilidade, e para contribuir com a compreensão dos conteúdos dos mesmos.

A unidade possui muitos textos com imagens coloridas, as quais chamam a atenção dos estudantes. A partir disto, observa-se a predominância de textos multimodais, os quais se constituem pela integração de textos escritos e imagens. Desse modo, eles despertam o interesse da criança pela leitura (TAVARES, 2010, p. 72) por meio dos recursos que auxiliam a interpretação.

Já os textos não verbais contribuem para a imaginação do estudante, ativando os conhecimentos prévios do mesmo, em relação aos objetivos e ao contexto em que o texto faz parte, relacionando-o ao tema da EA. Já os textos verbais apresentados na unidade, fazem parte do gênero de texto "aviso", podese inferir que, provavelmente, os estudantes já estão familiarizados a este gênero. 


\section{Visão de meio ambiente para o ensino e funcionalidade dos textos}

O segundo texto da unidade inicia um trabalho completo sobre o gênero de texto "campanha". As atividades referentes a este texto abordam os conhecimentos prévios sobre cuidados com os animais de estimação; identificação do gênero de texto; análise sobre o objetivo original da campanha; organização que produziu a campanha; público alvo; estudo linguístico discursivo sobre o verbo no modo imperativo; estratégias utilizadas por campanhas para atrair o público alvo. E, ao concluir as atividades, temos a intertextualidade com outra campanha com a temática sobre prevenção dos maus tratos aos animais.

Podemos entender que esta atividade embasada no gênero de texto, pode guiar o trabalho seguinte do professor, pois o mesmo tem autonomia de inserir outras atividades que contribuam com a aprendizagem dos estudantes.

As próximas atividades têm objetivos diferentes, como: a reflexão sobre a defesa dos animais; ensino de vocabulário; busca de informações precisas do texto; análise de elementos linguístico-discursivos de campanhas, avisos, entre outros gêneros de texto.

Nas atividades que exploram o gênero de texto "campanhas" é possível relacionar os conceitos de respeito mútuo dos homens para com os animais. Cada campanha aborda uma temática que pode ser problematizada e relacionada ao tema do meio ambiente, como: denúncia de exploração de animais; prevenção à exploração dos animais; adoção de animais; ajuda online aos animais e desenvolvimento de empatia e compaixão pelos animais. Percebe-se que mesmo as temáticas das campanhas sendo diferentes, em cada atividade da unidade um elemento do gênero é abordado individualmente para o ensino de língua.

Para classificar se a concepção de meio ambiente dos textos presentes nessa unidade são natural, racional ou histórica (TOZONI-REIS, 2001) foram observados os textos de modo geral, considerando como a) as imagens representam o relacionamento entre os seres vivos na sociedade; b) o texto verbal se relacionava com o texto não verbal, ou, se um ou outro foi inserido didaticamente, apenas para ser um tópico gramatical abordado; c) quais 
conhecimentos prévios o texto exige que estudante recupere para construir relações de significados com o texto; d) implicitamente, quais posicionamentos os textos sugerem que o estudante tenha em relação aos animais na sociedade.

Para ilustrar esta análise, realizamos a identificação dos gêneros de textos da unidade do (LD), e as visões do meio ambiente exploradas nas atividades. Além disso, de acordo com os objetivos das atividades para o ensino de língua inglesa, classificamos os textos utilizados em pretexto ou objeto de ensino. 
Quadro 2 - Identificação dos gêneros de textos da unidade do (LD), e as visões do meio ambiente exploradas nas atividades.

\begin{tabular}{|c|c|c|c|}
\hline Texto & $\begin{array}{l}\text { Página } \\
\text { do (LD) }\end{array}$ & $\begin{array}{l}\text { Identificação do } \\
\text { gênero de texto }\end{array}$ & $\begin{array}{l}\text { Visão sobre o meio Ambiente: Natural (N), Racional (R) ou } \\
\text { Histórica }(H) \text { (TOZONI-REIS, 2001) }\end{array}$ \\
\hline 1 & p.120 & $\begin{array}{l}\text {-/ Imagens } \\
\text { variadas com } \\
\text { uma oração }\end{array}$ & H - são os animais que pedem ajuda para os homens. \\
\hline 2 & p.122 & Campanha & H-ensinamento e problematização de valores e atitudes. \\
\hline 3 & p.123 & $\begin{array}{l}\text { - Imagem } \\
\text { (Ilustração) }\end{array}$ & $\begin{array}{l}\text { R-imagem ilustrativa- preparar o sujeito para utilizar os } \\
\text { conhecimentos e não praticar mais aquele ato. }\end{array}$ \\
\hline 4 & p.123 & $\begin{array}{l}\text { - I Imagem } \\
\text { (Ilustração) }\end{array}$ & $\begin{array}{l}\text { R-imagem ilustrativa- preparar o sujeito para utilizar os } \\
\text { conhecimentos e não praticar mais aquele ato. }\end{array}$ \\
\hline 5 & p.123 & $\begin{array}{l}\text { - I Imagem } \\
\text { (Ilustração) }\end{array}$ & $\begin{array}{l}\text { R-imagem ilustrativa- preparar o sujeito para utilizar os } \\
\text { conhecimentos e não praticar mais aquele ato. }\end{array}$ \\
\hline 6 & p.124 & Campanha & H-solicita ética do homem para com a natureza. \\
\hline 7 & p.125 & - / Imagens & $\begin{array}{l}\mathbf{N} \text {-animais em seus habitats naturais e implicitamente, } \\
\text { imposição/regra social dos animais próprios para serem de } \\
\text { estimação. }\end{array}$ \\
\hline 8 & p.126 & $\begin{array}{l}\text { - I Imagem } \\
\text { (Ilustração) }\end{array}$ & (não apresenta) \\
\hline 9 & p.127 & Reportagem & $\begin{array}{l}\text { H-articulação de conhecimentos/fatos sociais (história) e a } \\
\text { importância da relação necessária e vantajosa com os animais } \\
\text { (natureza). Reafirma conceitos de respeito, solidariedade, } \\
\text { parceria, interdependência. }\end{array}$ \\
\hline 10 & p.128 & Campanha & $\begin{array}{l}\text { H-possibilitar um repensar sobre os fatores de comercialização de } \\
\text { animais. }\end{array}$ \\
\hline 11 & p.129 & Aviso & $\begin{array}{l}\text { R-preparar o sujeito para entender o limite que deve ter com as } \\
\text { espécies animais. }\end{array}$ \\
\hline 12 & p.129 & Aviso & $\begin{array}{l}\text { R-preparar o sujeito para entender o limite que deve ter com as } \\
\text { espécies animais. }\end{array}$ \\
\hline 13 & p.130 & Campanha & $\begin{array}{l}\text { H-evidenciar a possibilidade do humano de ajudar os animais por } \\
\text { meio de recursos tecnológicos. }\end{array}$ \\
\hline 14 & p.130 & Aviso & $\begin{array}{l}\text { R-preparar o sujeito para entender o limite que deve ter com as } \\
\text { espécies animais. }\end{array}$ \\
\hline 15 & p.130 & Tirinha & (Não é sobre o temática meio ambiente) \\
\hline 16 & p.130 & Tirinha & (Não é sobre o temática meio ambiente) \\
\hline 17 & p.131 & $\begin{array}{l}\text { Anúncio de } \\
\text { serviço público } \\
\text { (em áudio) }\end{array}$ & $\begin{array}{l}\text { H-denunciar atitudes correspondentes à falta de respeito entre } \\
\text { homem e natureza no comércio de produtos de limpeza, higiene } \\
\text { pessoal e farmacêutica, e, além disso, possibilitar uma } \\
\text { aprendizagem sobre fatos muitas vezes desconhecidos pela } \\
\text { sociedade e de meios de informação sobre as indústrias praticantes } \\
\text { da exploração animal. }\end{array}$ \\
\hline 18 & p.131 & - / Imagem & $\begin{array}{l}\text { H-proporcionar uma curiosidade sobre quais são os produtos } \\
\text { comuns que são testados em animais. Como essa atitude tornou- } \\
\text { se uma prática aceita cultural e socialmente. }\end{array}$ \\
\hline 19 & p.131 & - / Imagem & $\begin{array}{l}\text { H-proporcionar uma curiosidade sobre quais são os produtos } \\
\text { comuns que são testados em animais. Como essa atitude tornou- } \\
\text { se uma prática aceita cultural e socialmente. }\end{array}$ \\
\hline 20 & p.131 & - / Imagem & $\begin{array}{l}\text { H-proporcionar uma curiosidade sobre quais são os produtos } \\
\text { comuns que são testados em animais. Como essa atitude tornou- } \\
\text { se uma prática aceita cultural e socialmente. }\end{array}$ \\
\hline 21 & p.133 & Campanha & $\begin{array}{l}\text { H- Comparar as características dos seres vivos, visando causar } \\
\text { empatia, reflexão sobre atitudes prejudiciais ao animal e ao meio } \\
\text { ambiente }\end{array}$ \\
\hline
\end{tabular}

Fonte: as autoras

\footnotetext{
${ }^{6}$ Gostaríamos de esclarecer que não consideramos "imagens" como gênero de texto. As palavras "imagens" são inseridas, para demonstrar que nas páginas que não apresentam gêneros de texto. Na unidade são colocadas imagens relacionadas ao tema sobre os animas, para auxiliar no objetivo da atividade.
} 
Imagem 2- Representação dos dados do quadro 2

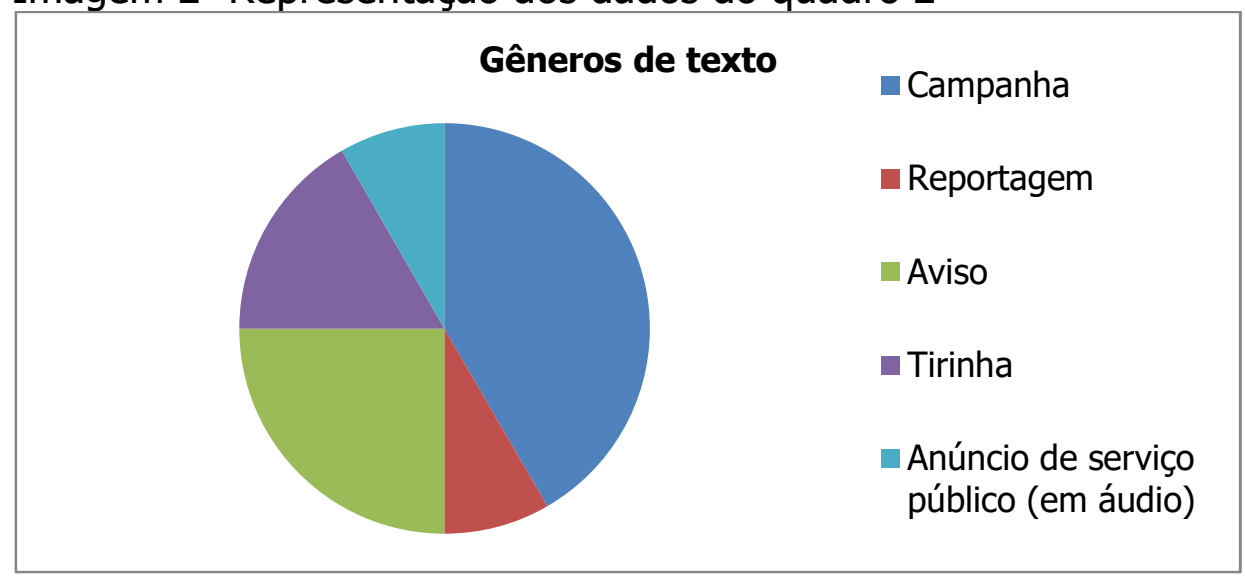

Fonte: as autoras

Imagem 3- Representação dos dados do quadro 2

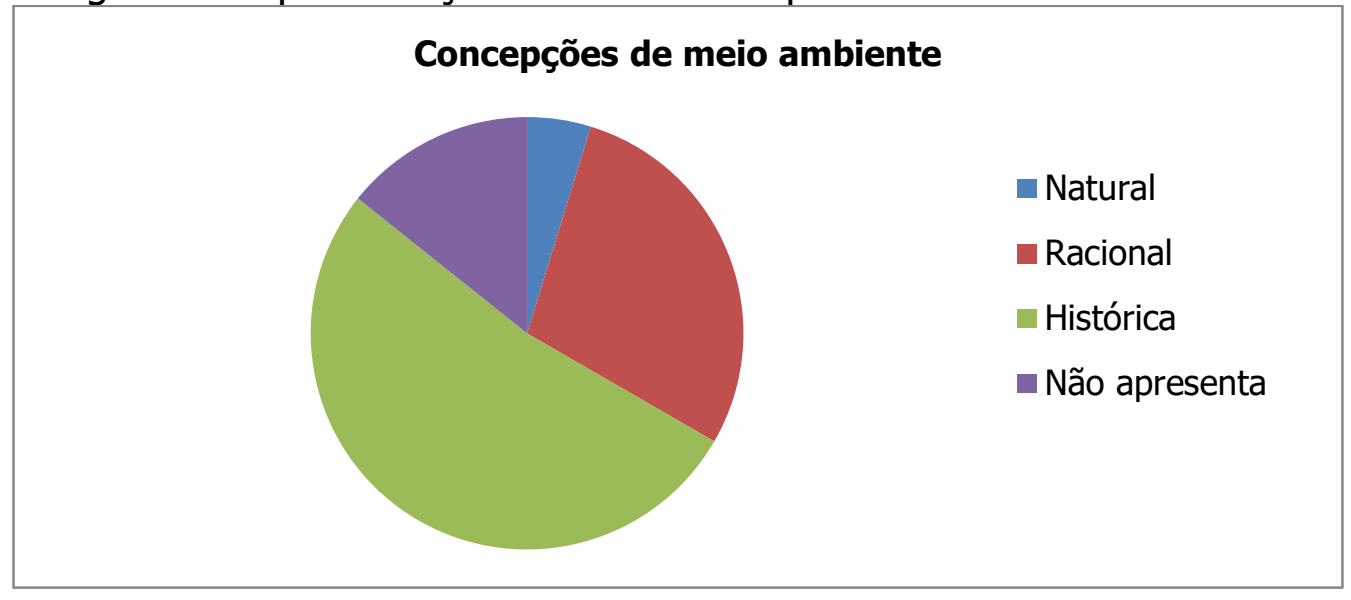

Fonte: as autoras

Os gêneros de texto predominantes na unidade são "campanhas", e, considerando que se trata de um sexto ano, há muita representação de animais, por meio de imagens. Estas objetivam o auxílio ao ensino de novo léxico em língua estrangeira, pois nesta faixa etária, os estudantes estão apropriando-se de vocabulário, para conseguir atribuir sentidos para os textos mais complexos. Obviamente, trabalhar o léxico a partir de textos que estejam contextualizados em relação ao tema é uma alternativa metodológica de ensino. Mas ao entender o (LD) como um norteador para a prática docente, analisa-se que as atividades com foco no léxico pretendem fornecer uma base para o ensino. Porém, um ponto negativo deste trabalho é pode perder o foco da problematização do tema relacionado à $(E A)$. 
Em relação à visão de meio ambiente (TOZONI-REIS, 2001) das atividades, percebe-se a predominância da visão Histórica. Mesmo nas imagens inseridas durante a unidade, de acordo com o objetivo de cada atividade são trabalhados vários aspectos históricos sobre a relação homens e animais em diferentes contextos sociais.

Nos textos são abordados como o ser humano deveria agir ou comportarse em determinadas situações em que estão em contato com diferentes espécies de animais, assim sendo, inclui valores e incentiva práticas críticas e sociais aos estudantes.

Além disso, até mesmo o trabalho com os verbos no modo imperativo, nos textos da unidade, implica na importância e urgência de fazer este problema social ser conhecido, para que os cidadãos estejam preparados para lidar consciente e criticamente, ao deparar-se com este tipo de situação no cotidiano.

\section{Didatização do gênero de texto}

Em relação à problematização do conceito de autenticidade de textos no(LD) proposta por Meinhof (1987 apud WALLACE, 1996), percebe-se nos textos da unidade analisada, que a autenticidade do gênero não é a mesma depois que ele está fora do contexto original de produção, pois seus objetivos e funcionalidade mudam devido ao suporte que está inserido e aos interlocutores a que se refere.

Entretanto, assim como explica Breen (1985 apud WALLACE, 1996) existem meios de explorar a autenticidade do texto. Para isto, depende do objetivo da atividade, da autenticidade do texto, envolvendo a compreensão do contexto de produção, desse modo, a autenticidade pode auxiliar na mediação da aprendizagem do ensino de línguas.

Vejamos a seguir os objetivos originais e didáticos dos textos que compõe a unidade do (LD) analisado. 
Quadro 3 - Objetivos originais e didáticos dos textos

\begin{tabular}{|c|c|c|}
\hline Texto & $\begin{array}{c}\text { Objetivo do texto no contexto } \\
\text { original }\end{array}$ & Objetivo didático \\
\hline 1 & Mostrar os animais. & $\begin{array}{l}\text { Ativar o conhecimento prévio do estudante } \\
\text { sobre animais domésticos e selvagens. }\end{array}$ \\
\hline 2 & $\begin{array}{l}\text { Encorajar a denúncia de maus } \\
\text { tratos aos animais. }\end{array}$ & $\begin{array}{l}\text { Analisar os elementos composicionais do } \\
\text { cartaz; analisar o objetivo do texto; interpretar } \\
\text { as informações do texto. }\end{array}$ \\
\hline 3 & Ilustrar um animal sofrendo & Evidenciar situação de risco para o animal. \\
\hline 4 & Ilustrar um animal sofrendo & Evidenciar situação de risco para o animal. \\
\hline 5 & Ilustrar um animal sofrendo & Evidenciar situação de risco para o animal. \\
\hline 6 & $\begin{array}{l}\text { Representar a prevenção ao abuso } \\
\text { de animais. }\end{array}$ & Retomar o conteúdo dos textos anteriores. \\
\hline 7 & Mostrar o animal. & $\begin{array}{l}\text { Ensinar vocabulário sobre animais domésticos } \\
\text { e selvagens. }\end{array}$ \\
\hline 8 & Ilustrar/mostrar animais. & $\begin{array}{l}\text { Ensinar vocabulário sobre animais domésticos } \\
\text { e selvagens. }\end{array}$ \\
\hline 9 & $\begin{array}{l}\text { Informar sobre as vantagens de } \\
\text { cães guia para cegos. }\end{array}$ & $\begin{array}{l}\text { Ler, interpretar o texto, associar as } \\
\text { informações corretas do texto; novo } \\
\text { vocabulário. }\end{array}$ \\
\hline 10 & Incentivar a atitude de adoção. & $\begin{array}{l}\text { Analisar objetivo do texto; elementos } \\
\text { referenciais; sinônimos; verbos no imperativo. }\end{array}$ \\
\hline 11 & Alertar perigo. & $\begin{array}{l}\text { Identificar verbos no imperativo; analisar } \\
\text { possível contexto de circulação; relacionar ao } \\
\text { tema animais selvagens. }\end{array}$ \\
\hline 12 & Solicitar e estabelecer uma regra. & $\begin{array}{l}\text { Identificar verbos no imperativo; analisar } \\
\text { possível contexto de circulação; relacionar ao } \\
\text { tema animais selvagens. }\end{array}$ \\
\hline 13 & $\begin{array}{l}\text { Conscientizar sobre a ajuda aos } \\
\text { animais. }\end{array}$ & Analisar a função do verbo no imperativo. \\
\hline 14 & Alertar perigo. & Analisar a função do verbo no imperativo. \\
\hline 15 & Provocar humor/reflexão & Analisar a função do verbo no imperativo. \\
\hline 16 & Provocar humor/reflexão & Analisar a função do verbo no imperativo. \\
\hline 17 & $\begin{array}{l}\text { Conscientizar sobre o abuso de } \\
\text { animais em indústrias, para testes. }\end{array}$ & Identificar as informações do texto. \\
\hline 18 & Mostrar um shampoo. & Retomar informações do texto anterior. \\
\hline 19 & Mostrar remédios. & Retomar informações do texto anterior. \\
\hline 20 & Ilustrar produtos de limpeza. & Retomar informações do texto anterior. \\
\hline 21 & $\begin{array}{l}\text { Expressar/promover a compaixão } \\
\text { aos animais }\end{array}$ & $\begin{array}{l}\text { Promover reflexão sobre exploração dos } \\
\text { animais pela indústria; possíveis soluções para } \\
\text { a extinção dos animais }\end{array}$ \\
\hline
\end{tabular}

Fonte: as autoras 
Quadro 4 - Pretexto ou objeto de ensino de um gênero textual

\begin{tabular}{|c|c|}
\hline Texto & $\begin{array}{l}\text { Pretexto }(P) \text { para o ensino de língua } \\
\text { (ou) Objeto de ensino (OE) de um gênero textual }\end{array}$ \\
\hline 1 & $P$ \\
\hline 2 & $\mathrm{OE}$ \\
\hline 3 & $P$ \\
\hline 4 & $P$ \\
\hline 5 & $\mathrm{P}$ \\
\hline 6 & $P$ \\
\hline 7 & $P$ \\
\hline 8 & $P$ \\
\hline 9 & $\mathrm{OE}$ \\
\hline 10 & $\mathrm{OE}$ \\
\hline 11 & $P$ \\
\hline 12 & $\mathrm{P}$ \\
\hline 13 & $P$ \\
\hline 14 & P \\
\hline 15 & $P$ \\
\hline 16 & $\mathrm{P}$ \\
\hline 17 & $\mathrm{OE}$ \\
\hline 18 & $P$ \\
\hline 19 & $\mathrm{P}$ \\
\hline 20 & $P$ \\
\hline 21 & $\mathrm{OE}$ \\
\hline
\end{tabular}

Fonte: as autoras 


\section{Imagem 4 - Objetivo original do texto}

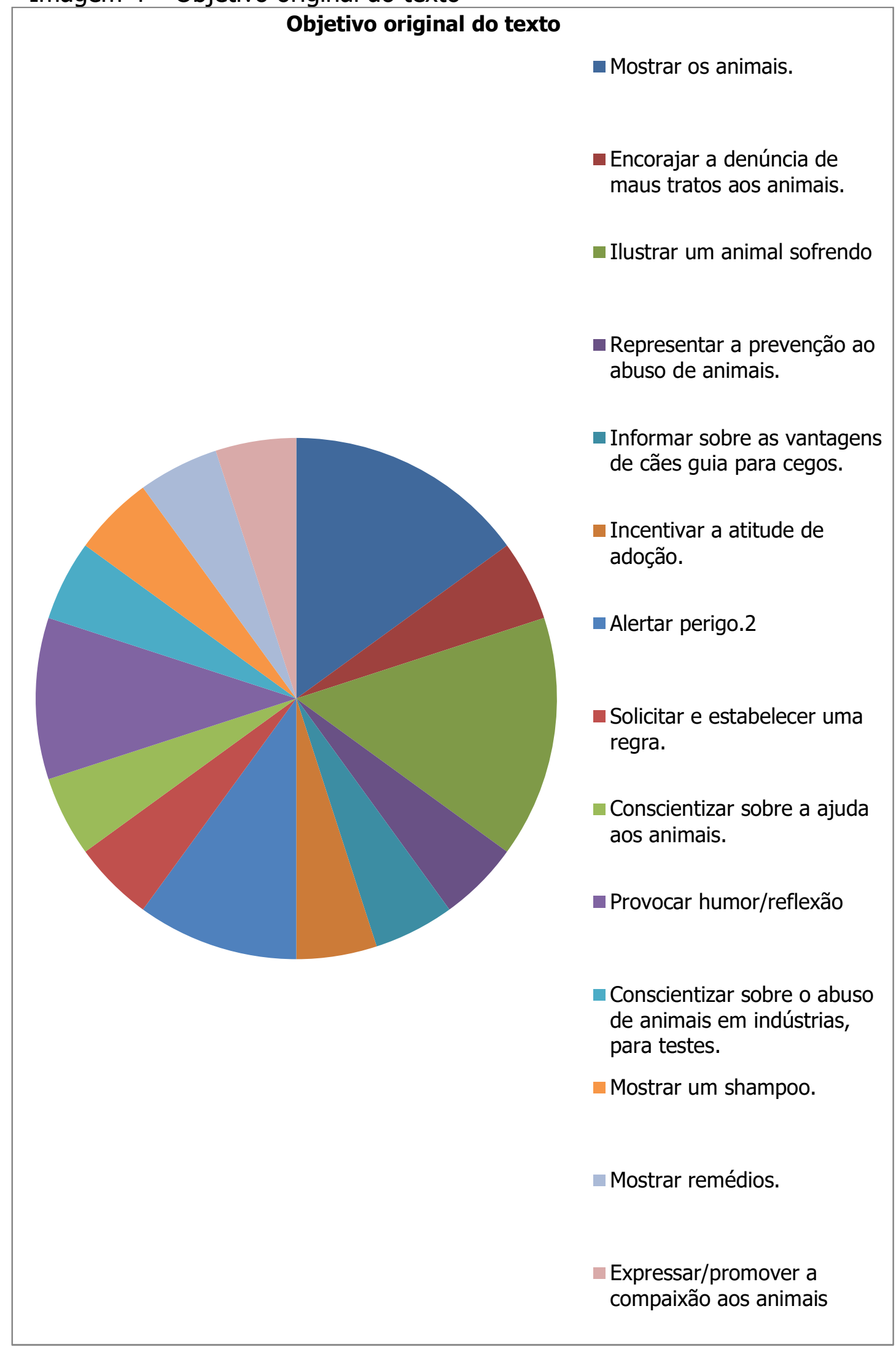

Fonte: As autoras. 
Imagem 5 - Representação dos dados do quadro 3

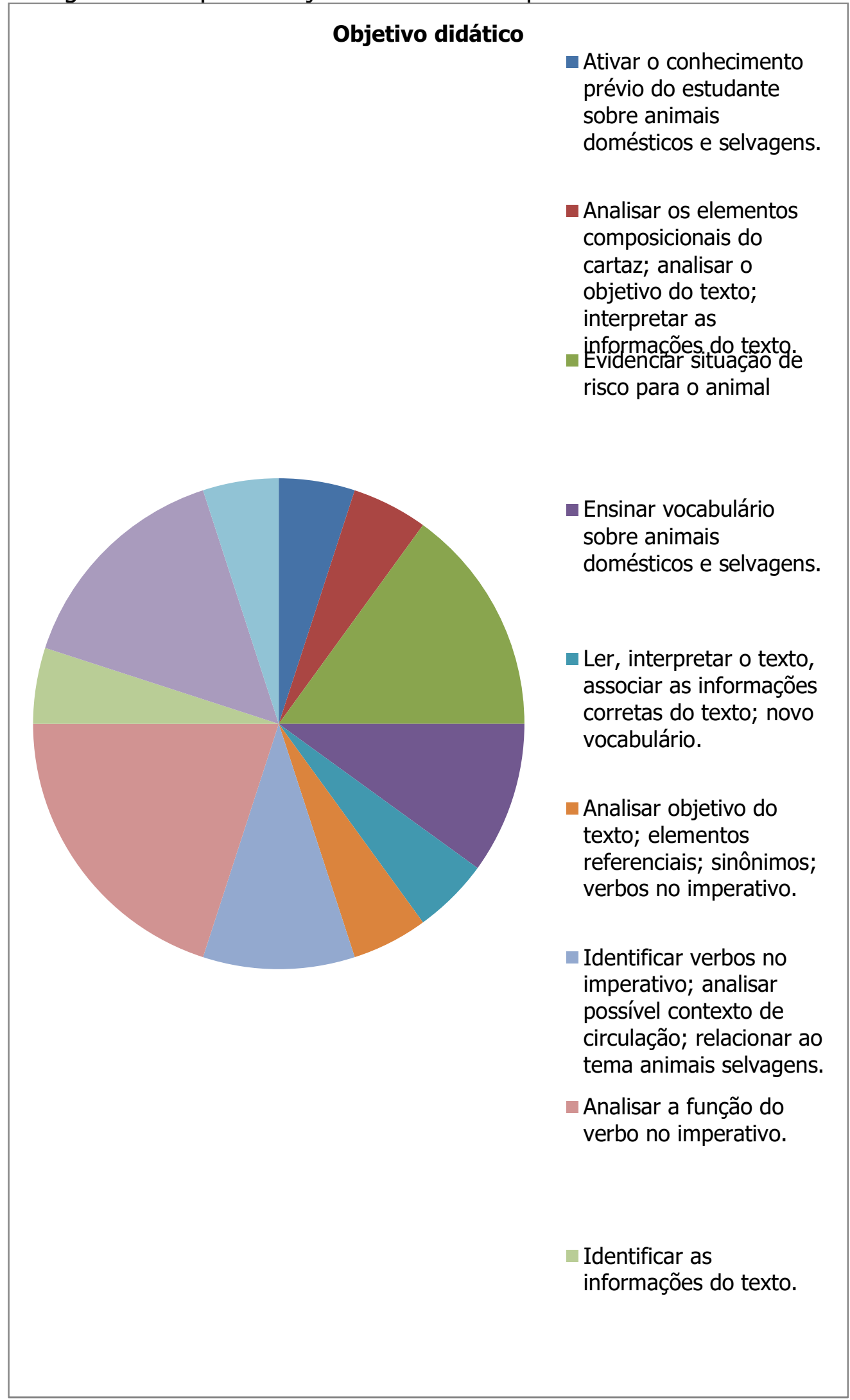

Fonte: as autoras. 
Imagem 6- Representação dos dados do quadro 4

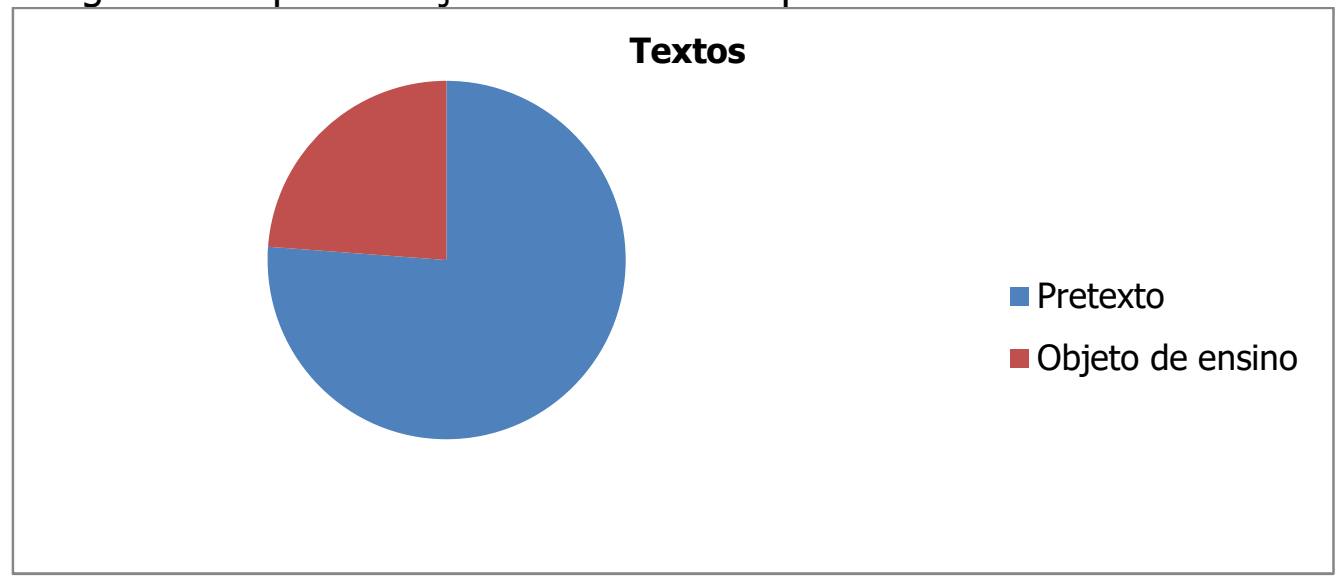

Fonte: as autoras

O quadro 3 evidencia a alteração de objetivo dos textos ao saírem de seu contexto original e passarem para o suporte do (LD). Isto prova que a funcionalidade do texto muda de acordo com o objetivo de ensino, da linguagem e dos interlocutores.

Percebe-se que há uma variedade de gêneros de textos na unidade didática. Mas, a maioria deles é utilizada como $\mathrm{P}$ para ensino de léxico sobre $\mathrm{O}$ nome dos animais em Língua Inglesa, e também sobre o modo verbal imperativo. Eles focam em questões gramaticais ou noensino do léxico. Já os textos considerados OE englobam o gênero de texto "campaign poster". Nas atividades mais completas e mais complexas, por exemplo, analisam-seos níveis textuais, e influenciam a reflexão sobre a temática estudada.

Podemos observar a recorrência de textos utilizados como $\mathrm{P}$ para o ensino de elementos gramaticais da língua estrangeira. Não podemos afirmar que as atividades estão descontextualizadas, pelo fato de elas pertencerem a um tópico/seção específico de ensino da unidade do (LD).

As atividades $P$ não devem ser consideradas inferiores às que são entendidas como $\mathrm{OE}$, pois no decorrer da unidade cada uma tem a sua função, porém os elementos trabalhados em atividades encaradas como $P$ também poderiam ser abordados nas atividades $\mathrm{OE}$, depende o modo como o professor encara o gênero apresentado e o relaciona com objetivos linguísticos e temáticos a serem ensinados. 
São utilizadas atividades $\mathrm{P}$ para exercícios de fixação de vocabulário e práticas de elementos linguísticos presentes nos textos, com isto, podemos sugerir que esses elementos também sejam trabalhados a partir de gêneros de texto contextualizados e relacionados à temática que está sendo estudada. Alguns textos inseridos durante a unidade estão presentes na atividade apenas por mostrar o modo verbal imperativo, isto dificulta a análise linguística (tempo verbal, vocabulário, ou efeitos de sentido) em relação à situação de comunicação e problematização proposta pela (EA).

No decorrer desta unidade, os cinco textos que são considerados $\mathrm{OB}$, são bases para atividades que trabalham os elementos linguísticos, proporcionando à interpretação, compreensão e reflexão da temática, dentre eles, apenas três são pôsteres de campanhas de uma mesma instituição. Os outros dois gêneros pertencem à mesma temática, porém não são da mesma instituição e possuem objetivos originais diferentes.

Ao final da unidade, na página 132, é sugerida a produção de um pôster de campanha, e alguns temas são elencados, como: adoção de animais de estimação; direitos dos animais ou um protesto contra testes em animais, entre outros. Pode-se analisar se os objetivos das campanhas são os mesmos, os possíveis interlocutores e o modo que abordam o tema se difere das campanhas apresentadas pelo (LD). Fica evidente que o professor deve ter autonomia para complementar o trabalho, apresentando-Ihes pôsteres de campanhas de outras instituições, que se relacionem à temática estudada.

Observa-se que as atividades da unidade do (LD) são organizadas de um modo que se relacionam ao tempo de trabalho em sala de aula e o número de aulas de língua inglesa do sexto ano. Mas, considerando uma sugestão da (EA) crítica, o docente pode relacionar o tema da unidade do (LD) com o contexto local dos estudantes. Por exemplo, anterior ao trabalho de produção escrita do pôster, pode ser feito trabalhos de entrevistas, enquetes e pesquisas com a comunidade escolar sobre o tema da unidade.

Atemática desta unidade pode ser expandida em um projeto extraclasse, ampliado os conhecimentos críticos dos estudantes em relação ao que estão 
estudando. A interdisciplinaridade poderia ser trabalhada na disciplina de ciências com o tema sobre a cadeia alimentar dos seres vivos. Em português, o professor poderia auxiliar na explicação sobre o tipo e função da linguagem utilizada em campanhas com o objetivo de conscientizar a sociedade. Em arte, o docente poderia auxiliar na confecção dos cartazes, explicando a importância o layout do texto e quais o como os significados das cores que podem ser utilizadas, influenciam nos efeitos de sentidos que queremos atribuir aos leitores. $O$ professor de história poderia explicar a relação do consumismo na sociedade, resgatando nos primórdios da sociedade, os motivos pelos quais o homem utiliza a "força" animal para o trabalho. A disciplina de geografia poderia abordar conteúdos sobre espécies animais relacionando-as às regiões do país. O professor de matemática poderia ensinar os estudantes a fazerem um estudo sobre a quantidade de animais de estimação da comunidade, em relação ao número de estudantes.

As sugestões acima reforçam um trabalho que seja significativo aos estudantes, para que os mesmos associem os conhecimentos trabalhados em outras disciplinas, e, a partir disto, ampliem os conceitos críticos sobre a temática da $(E A)$, sentindo-se parte responsável do meio ambiente.

\section{Considerações Finais}

A partir do que foi apresentado, entendemos o (LD) como gênero, pois ele agrupa vários gêneros de textos, selecionados com objetivos de ensino. Entretanto, os gêneros ao saírem da esfera de circulação original e estarem inseridos em um gênero com objetivo metalinguístico, passam a ter um objetivo didático, que neste caso visa o ensino da linguagem.

$\mathrm{Na}$ unidade analisada é recorrente a presença de textos multimodais e não verbais. Isto ocorre, principalmente, devido à faixa etária dos estudantes, para auxiliá-los no processo de ensino e aprendizagem, facilitando a representação de novos conceitos. 
A variedade de gêneros de textos é um ponto positivo para a aprendizagem, pois oportuniza o contato com diversas esferas de circulação, interlocutores e objetivos, dando acessibilidade a uma variedade de temas e prática de atividades com foco na aprendizagem de língua estrangeira.

A visão de meio ambiente (TOZONI-REIS, 2001) presente na maioria das atividades é a visão histórica. Mesmo muitas atividades terem como objetivo didatizado o ensino do léxico, e verbos no imperativo, a maioria dos textos mostram a necessidade de relacionamento entre seres humanos e natureza. Além disso, as imagens evidenciam a interdependência de ambos, no momento em que os colocam lado a lado ou mostram as consequências de atos desmedidos.

Secundariamente, a visão racional está implícita nos textos, pois visa mostrar que o ser humano deve buscar os recursos disponíveis, para uma convivência respeitosa com os animais. As visões de meio ambiente nos textos base para as atividades sugerem que o ser humano repense esta relação com a natureza. Considerando a faixa etária dos estudantes, é visto que o objetivo das atividades é a tomada de consciência sobre as relações sociais e possibilidades de ação frente às situações de sofrimento dos animais.

Notou-se também, a variação de objetivos originais e didáticos dos textos, com funcionalidades diferentes quando estão no (LD). Os objetivos originais da maioria dos textos utilizados na unidade eram a) apresentar os animais; b) mostrar animais sofrendo; c) representar a prevenção ao abuso dos animais. Percebe-se que o objetivo da escolha desses textos é a sensibilização dos estudantes em relação à temática estudada, pois este pode ser o primeiro contato deles com um tema ambiental encarado como uma problemática, pelo viés crítico.

Entendemos a importância do conceito de sustentabilidade nas atividades, pois ele baseia um ensino que resgata questões históricas e políticas. Também objetiva a transformação humana, ressalta atitudes de responsabilidade e respeito geral na sociedade, buscando assim, o equilíbrio na diversidade ambiental. 
Por conseguinte, entendemos como um desafio associar este conceito com o ensino de línguas e o ensino da (EA) histórico crítica, pois todos eles são complexos e interdependentes, por isto, questionamos a predominância de um conceito em relação ao outro.

Portanto, como tentativa de um trabalho efetivo envolvendo o tema (EA), o apoio interdisciplinar é de suma importância, pois visa facilitar o ensino e a aprendizagem. Além disso, é necessária a análise cuidadosa da unidade do (LD) por parte do docente. Este que preparará das aulas associando os elementos propostos para o ensino de elementos linguísticos-discursivos da língua inglesa, coma criticidade do tema (EA).

Certamente para que a aprendizagem se efetive a partir da prática, é preciso acontecer a tomada de consciência, por parte dos estudantes, sobre 0 que está sendo estudado. E para isto seriam necessárias mais aulas, para trabalhar esses os conceitos, de modo crítico e global.

\section{Referências}

BONINI, Adair. Gêneros e projetos de trabalho no livro didático: uma análise de dois manuais. In: ENCONTRO CELSUL - CÍRCULO DE ESTUDOS LINGÜÍSTICOS DO SUL, 6., 2011, Florianópolis, SC. Anais eletrônicos [...]. Florianópolis: Universidade Federal de Santa Catarina, 2004. p. 1-6. http://www.leffa.pro.br/tela4/Textos/Textos/Anais/CELSUL_VI/index.htm

BONINI, Adair. Mídia/ suporte e hipergênero: os gêneros textuais e suas relações. Revista Brasileira de Linguística Aplicada: RBLA, Belo Horizonte, v. 11, n. 3, p. 679-704, 2011.

BONINI, Adair. Veículo de comunicação e gênero textual: noções conflitantes. DELTA: Documentação e Estudos em Linguística Teórica e Aplicada, São Paulo, v. 19 , n. 1 , p. $65-89,2003$.

BRASIL. Ministério da Educação. Secretaria de Educação Básica Base Nacional Comum Curricular. Documento para consulta pública. Brasília, DF: MEC, 2015.

CONFERÊNCIA INTERGOVERNAMENTAL DE TBILISI, 1., 1977, Tbilisi, Georgia, Russia. Anais eletrônicos [...]. UNESCO: PNUMA, 1977. Tema: Educação Ambiental. Disponível em: 
http://www.ufpa.br/npadc/gpeea/DocsEA/ConfTibilist.pdf. Acesso em: 2 ago. 2017.

DIAS, Bárbara de Castro; BONFIM, Alexandre Maia. A "teoria do fazer" em educação ambiental crítica: uma reflexão construída em contraposição à educação ambiental conservadora. In: ENCONTRO NACIONAL DE EM EDUCAÇÃO EM CIÊNCIAS, 8., 2011. Atas [...]. Campinas, SP. Campinas: Universidade Estadual de Campinas, 2011. p. 1-9. Disponível em:

http://abrapecnet.org.br/atas_enpec/viiienpec/listaresumos.htm. Acesso em: 2 ago. 2017.

FRANCO, Cláudio de Paiva; TAVARES, Kátia Cristina do Amaral. Way to English 6: for Brazilian leanners. São Paulo: Editora Ática, 2015. v. 1.

GUIMARÃES, Ana Maria de Mattos. Didatização do gênero: um desafio. In: ENCONTRO CELSUL - CÍRCULO DE ESTUDOS LINGÜÍSTICOS DO SUL, 6., 2011, Florianópolis, SC. Anais eletrônicos [...]. Florianópolis: Universidade Federal de Santa Catarina, 2011. p. 1-8. Disponível em:

http://www.leffa.pro.br/tela4/Textos/Textos/Anais/CELSUL_VI/index.htm. Acesso em: 2 ago. 2017.

LEFF, Enrique. Saber ambiental. 6. ed. Petrópolis: Vozes, 2008.

MARCUSCHI, Luiz Antônio. A questão do suporte dos gêneros textuais. Língua, Lingüística e Literatura, João Pessoa, v. 1, n. 1, p. 9-40, 2003.

MARCUSCHI, Luiz Antônio. Gêneros textuais: definição e funcionalidade. In: DIONISIO, Ângela Paiva; MACHADO, Anna Rachel; BEZZERA, Maria Auxiliadora. (org.). Gêneros textuais e ensino. São Paulo: Parábola, 2010.

MORDENTE, Olga. Análise sociolinguística de manuais didáticos para o ensino de Italiano como língua estrangeira. São Paulo: Departamento de Linguística da FFLCH-USP, São Paulo, 1994.

REIGADA, Carolina; TOZONI-REIS, Marília Freitas de Campos. Educação ambiental para crianças no ambiente urbano: uma proposta de pesquisa-ação. Ciência \& Educação, Bauru, SP, v. 10, n. 2, p. 149-159, 2004.

SOUZA, Ester Maria de Figueiredo; VIANA, Layane Dias Cavalcante. Livro didático como gênero do discurso complexo. Anais do Silel, Uberlândia, MG, v. 2, n. 2, p. 1-10, 2011.

TAVARES, Lúcia Helena Medeiros da Cunha. Gêneros e multimodalidade discursiva nas histórias em quadrinhos. Prolíngua, João Pessoa, PB, v. 5, n. 2, p. 69-80, jul./dez. 2010. 
TEIXEIRA, Lucas André. Formação do educador ambiental: reflexões de um professor da escola pública. 2013. 276 f. Tese (Doutorado) - Faculdade de Ciências, Universidade Estadual Paulista, Bauru, SP, 2013.

TOZONI-REIS, Marília Freitas de Campos. Environmental education: theoretical references in higher education. Interface: Comunicação, Saúde, Educucação, Botucatu, SP, v. 5, n. 9, p. 33-50, 2001.

TOZONI-REIS, Marília Freitas de Campos. Temas ambientais como "temas geradores" contribuições para uma metodologia educativa ambiental crítica, transformadora e emancipatória. Educar, Curitiba, n. 27, p. 93-110, 2006.

TREIN, Eunice Schilling. A educação ambiental crítica: crítica de que? Revista Contemporânea de Educação, Rio de Janeiro, RJ, v. 7, n. 14, p. 304-318, ago./dez. 2012.

VENTURI, Maria Alice. Tópicos de aquisição e ensino de língua estrangeira. São Paulo, SP: Humanitas, 2008.

WALLACE, Catherine. The role of the text in the second language classroom. Oxford, OX: Oxford University Press, 1996. 